\title{
REFLECTION OF QUALITATIVE CHARACTERISTICS OF ACCOUNTING IN CULTURE; A CASE STUDY ON WAYANG IN YOGYAKARTA
}

\author{
Theresia Octapiani Eka Sari \\ Accounting Department, BINUS Graduate Program - Master of Accounting, \\ BINUS Business School Undergraduate Program, Bina Nusantara University
}

\section{Marko S. Hermawan}

International Business Management Program, Management Department, BINUS Business School Undergraduate Program, Bina Nusantara University

\begin{abstract}
Wayang, which is an original Javanese art, existed before Hindu culture entered Java. In addition to being an art, it is also a medium for conveying noble values to the community. The various stories in puppetry generally provide lessons for good and bad things to emulate them. An effort to find out the relationship between puppet stories and the formation of accounting science characteristics in Indonesia is by conducting interviews with several puppeteers who have been practicing puppetry from 42-59 years ago. Based on the results of interviews with informants, there are qualitative characteristics of accounting in Wayang stories. The Mahabharata story describes a market as a medium of power and Tondo as an economic actor who pays taxes to the state. The ethics and economic morals taught are honesty, Seruni as the corruptor, and Turo as the honest play. The qualitative characteristics of accounting in Wayang stories are not shown absolutely or directly, but only as a form of symbolization.
\end{abstract}

Key words: Wayang, Accounting, Qualitative, Puppets, Javanese, Yogyakarta

Cite this Article: Theresia Octapiani Eka Sari and Marko S. Hermawan, Reflection of Qualitative Characteristics of Accounting in Culture; A Case Study on Wayang in Yogyakarta, International Journal of Management, 11(12), 2020, pp 1910-1917.

http://iaeme.com/Home/issue/IJM?Volume=11\&Issue $=12$ 


\section{INTRODUCTION}

The environment shapes accounting through very complex social interactions (Sylvia 2014). Consequently, accounting is part of social science formed by humans; it has a relationship and influence from human existence in a community group. Tricker (1978) and Triyuwono (2009) explain that accounting is a social product or cultural product created from concepts of human minds' based on creativity, taste, and human intention. It is thus imperative to observe the uniqueness between accounting characteristics in a specific setting, in this case, Indonesia's traditional culture

Much cultural heritage is the attraction and characteristics of each region. The attractiveness and characteristics of this is a very valuable asset and is a source of wealth that will never run out if we, the Indonesian people, can preserve and manage it. However, people do not realize it; the era of globalization has also brought foreign culture to threaten the Indonesian national identity loss. As part of national culture, regional culture is the Indonesian nation's identity that will be eroded and lost if the guidance and appreciation of it get smaller.

Indonesia has a wide variety of ethnic groups, of course, has a diversity of cultural arts. Each tribe and even each region has its uniqueness, which becomes an attractive cultural tourism potential if managed optimally. The form of this can be in the form of items of artistic value or performing arts. The Javanese are one of the Indonesian ethnic groups who have a wealth of regional cultural treasures that we still know today. Many regions in Java are still trying to preserve the existence of traditional arts. According to Ravhani and Muryadi (2012) in Widhianningrum $\mathrm{P}$ and Amah N (2014), traditional arts, including traditional folk performing arts, have a function, both as ritual and public entertainment. Performing arts have a ritual function as a prerequisite for an event or traditional ceremony. Meanwhile, the function of performing arts as entertainment is packaged and displayed aesthetically and has a selling value.

This paper oversees the extent to which traditional culture and performance provide elements of qualitative characteristics of accounting. The authors observe 'Wayang kulit' art in Yogyakarta to determine whether the 'Wayang kulit' stories reflect accounting values. Wayang Kulit show was recognized by UNESCO on November 7, 2003, as cultural workers in narrative stories and beautiful and precious heritage (Masterpiece of Oral and Intangible Heritage of Humanity). As the Wayang kulit is more popular in central and eastern Java, this research observes one story's phenomenon in one area, namely Yogyakarta.

On the other hand, research on accounting practices using a qualitative approach has been carried out by many researchers; one example is Sukoharsono (2009). The study results by Sukoharsono (2009) concluded that accounting had been understood as another form of social society that requires social, political, and cultural values. The lack of references to scientific reflection in local culture motivates to bridge research between Javanese culture, which is reflected in the form of Wayang kulit, which is linked to accounting. Based on the background description above, this research considers 'How is the construction of the accounting concept in XYZ's Wayang kulit art in Yogyakarta which is full of local cultural values?' This research is expected to add insight and knowledge and become a reference material in researching a cultural anthropology study with modern accounting. To be more precise, see how culture can influence the accounting system, namely Javanese-style accounting. In this case, it is so that the shadow puppet community knows that so far, accounting has been implied in the Wayang story. 


\section{INDONESIAN WAYANG KULIT CHARACTERISTICS}

Some examples of traditional folk performing arts developed in Central Java include Wayang kulit, Wayang orang, and ketoprak. Due to the influence of global cultural currents, which argues of being modernization, many traditional folks performing arts have been marginalized, as one example is Wayang kulit. Wayang comes from the word "Ma Hyang" which means leading to a spiritual spirit, god, or God Almighty. Wayang kulit is a high-value culture because apart from being a craft art, shadow puppet performances can combine various kinds of arts such as literature, music, and fine arts. The literary art of pupuh is pronounced by the puppeteer, the art of music from the chanting of various names of traditional musical instruments, and the fine art of the visualization of Wayang kulit, which is unique distinctively Indonesian culture.

According to Sutrisno (2005), Wayang is a reflection and role model of life; in the past, it was a culture whose values were used as life guided by the community. Besides that, Wayang is used as a means of ritual performance and is a form of religious rites.

Puppet performances in the past were a ritual ceremony for the worship of ancestral spirits. This fact is still felt today. According to Sujamto in Suharyono (2005:26-27), this belief is closely related to ancient Indonesian beliefs, namely animism and dynamism. According to Mulyono (1983:53), in its development, Wayang performances are often used as educational media, da'wah media that contain noble values, shadow shows, or Wayang shows are also used in larungan, ruwatan, or clean village rituals, where people have a hope to be given salvation and avoid calamities and also get abundant blessings.

Javanese people in the past did have shadow performances, like other nations. Javanese performances are not of Indian or Chinese influence. This performance is used for the worship of ancestral spirits, and other ritual uses. According to Suharyono (2005:32), this shadow show was initially characterized by animism and dynamism, closely related to the native Javanese religion (agami jawi). According to Warto, Supriadi, and Margana (2011:10), Wayang is considered a form of 10 special arts because it has characteristics which in Javanese are called fairuhung and adipeni, namely very great, sublime, and also beautiful (ethics and aesthetics).

According to Bastomi (1995), Wayang is a fantasy depiction of human shadows. Also, in its development, Wayang performances are often used as a medium for education, and a medium for preaching that contains noble values (Mulyono 1983).

Further study in traditional Javanese and business context focuses on the values of the Javanese itself. Hermawan and Loo's (2019) develops a deep understanding of kekeluargaan (kinship), which comes from anthropological and sociological epistemologies. This study explores Javanese culture as the basis of the Indonesian business context. Qualitative and cultural approaches were designed to determine whether kinship norms existed in Indonesian workplaces today. Document analysis and semi-structured interviews were used to collect data. The findings indicate that kinship norms act based on Indonesian organizational culture respectfully and harmoniously. Three propositions are given to consider the importance of understanding kinship as a prominent Indonesian organizational culture. This study concludes the managerial and theoretical implications for the Indonesian business context.

In terms of the relationship between the Wayang and Accounting, Zulfikar et al. (2017) argue about understanding accounting entities' meaning and finding the meaning behind that understanding. This research was conducted by analytic philosopher named Semar. In his argument, there is a social and environmental approach to business, which is one way to appreciate local wisdom in doing business. Business practices in Indonesia are heavily influenced by indigenous cultures. Local wisdom is a guide for the Indonesian people in all 
aspects of life. One of the local wisdoms that influences the life of the Indonesian people is Javanese culture. The original Javanese culture is upheld by the Indonesian people in general. One of the principles of life that has been practiced to this day is the principle of 'Gotong Royong. This principle teaches people to help each other reduce the interests of others. The social interpretation of business entities aims to explain the social realities of the various management roles and responsibilities associated with the owners of the company's social and environmental effects. Research by Zulkifar et al. aims to understand the meaning of accounting entities and find the meaning behind that understanding.

Based on Manan's research (2014) focuses on accounting actors and users who are representations of people's economic activities in the lower middle class in Javanese society. Javanese culture influences business activities, which are the object of research. The Javanese culture in Semarang provides a different style of accounting practice. Accounting practices carried out due to the influence of Javanese culture will lead to Javanese accounting practices, namely accounting practices based on memory and experience, to become accustomed. In addition, the purpose of presenting the information needed by internal parties has been well fulfilled by using a neat and structured Javanese culture, although in the simplest form and not in accordance with accounting in general.

Kusdewanti et al. (2014) propose that fighting a 'power' at war is a tiring endeavor. This form of resistance will be more meaningful for the people's interests if it is carried out by and for the people. The metaphorical approach is used to examine the power wars. In-depth literature studies and interviews with cultural communities, cultural observers, and historians confirm that the metaphor of Bantengan and Topeng Malang is appropriate to describe this condition. The research results from the journal indicate that the existence of the Indonesian Multiparadigm Accounting Society (MAMI or Masyarakat Akutansi Multiparadigma Indonesia) is a form of resistance to Bantengan Accounting, which is the driving force for the development of accounting science towards independent Indonesian accounting.

Widhianningrum and Amah (2014) describe and interpret accounting practices in the ketoprak cultural arts community in Pati and find out the reconstruction of accounting concepts in the ketoprak cultural arts community, which is full of local cultural values. The research results from the journal indicate that the economic compensation obtained is only a means of preserving and ensuring the survival of the ketoprak art group. The results of the reconstruction of the accounting concept in the ketoprak cultural arts community show that accounting is seen as a recording activity related to numbers and calculations in economic activities that are full of honesty and responsibility values.

\section{RESEARCH METHOD}

The type of research used in this research is qualitative. According to Sugiyono (2014:8), qualitative research is research where the data from the research results are more concerned with interpreting the data found in the field. Meanwhile, according to Sukmadinata (2013:94), qualitative research aims to describe and analyze phenomena, events, social activities, attitudes, beliefs, perceptions of people's thoughts individually / in groups. In this study, observation and data collection were carried out directly to Yogyakarta. Observations were made directly to the Wayang kulit community.

The basis for collecting this data is to seek implicit and explicit information on the philosophy of Wayang kulit. After collecting data through interviews and observations, the researcher then conducted a further study by conducting a document analysis (Document Analysis) of various puppet reference books.

The data used in this study are primary data. According to Sugiyono (2014:193), primary sources are data sources that directly provide data to data collectors. The method used in this 
research is a survey method through direct interviews with shadow puppet players in Yogyakarta such as dalang, Sinden, music player, and other players by interviewing 10-15 people.

This study used the triangulation method (Triangulation methods). Document analysis is a social research method and is an important research tool in its own right and an invaluable part of most triangulation schemes, a combination of methodologies in studying the same phenomenon (Bowen, 2009). To seek convergence and verification, qualitative researchers usually use at least two resources using different data sources and methods. According to Bowen (2009), the purpose of triangulation is to provide a meeting of evidence that breeds credibility. Reinforcing findings across data sets can reduce the impact of potential bias by examining information gathered through various methods.

\section{FINDINGS AND DISCUSSION}

Researchers conducted direct interviews with several puppeteers in different locations to get an appropriate picture of the reflection of the qualitative characteristics of accounting in culture, especially Wayang. The result of the interview is that there are qualitative characteristics of accounting in Wayang stories.

Accounting is a financial information system, which aims to produce and report relevant information for various interested parties (Kartikahadi et al. 2016). According to Kieso et al. (2016), fundamental activities in accounting are the identification, recording, and communication of an organization's economic events to interested parties. Thus, in broad terms, accounting can be defined as the process of identifying, recording, and communicating the final results in the form of financial reports that reflect the state of the company to interested parties.

Based on the interviews conducted with Dalang 1, a puppeteer at the Sono Budoyo Museum, he said that there are stories in Wayang that describe trade and the economy.

Mahabharata is like this; for example, a play in a new market, a new market is a trade. Wiratha, which is a large country, held a market. However, the market does not sell staples. The market exists only to gain victory from the person who founded it, and it is a market for human trafficking. Then, holding a human race, whoever wins must be established in Wiratha's country. Wiratha's country could become bigger because there were pandawa ngayom there to become Tondo. Tondo is the head of the market, asking for tickets for trading. One of the Tondo figures is Kunto Dewo, whose job is to pay taxes.

One of the puppet stories that contain qualitative accounting reflections is the Mahabharata story in which there is a market that is described as a medium to achieve power. As well, Tondo is a job which has to collect taxes from traders and pay the results to the state or kingdom.

In addition, in the puppet stories, there are ethical values in the economy being told. It is about honesty in carrying out economic activities.

"Seruni is a character in the puppet symbolizing a character of dishonesty. Seruni who corrupts everything, which makes trouble among all of them too. This chrysanthemum is not honest because it is for yourself. I maten there but for myself. Do not let me be displaced from our position, whatever the situation is. This chrysanthemum remains like this. Seruni doesn't like Turo and Bisma, because their goal is to be honest. In Seruni's mind, if he is honest then he will not win anything ".

"In the puppet there is a character with the name Turo. Turo symbolizes purity. For example, when reporting something it must be as is, if the financial chapter is like this it should be reported like this, but there are people who don't like honesty, namely Seruni." 
Another value of Wayang, according to Dalang 1, is following Sutrisno (2005), where the function of Wayang is a reflection of role models living in the past whose values are used as life guided by the community.

"Wayang is also a symbol for all of us who are good and bad. The philosophy of the puppet is high when contemplated".

Another interview conducted with Dalang 2, a puppeteer at Taman Mini Indonesia Indah, is that there are stories related to trade and the economy. However, this is only symbolized in the form of a story.

"Puppet stories related to trade, tranquility and others. It is more dominant to be told".

"Wayang stories that are absolutely directly related to trade are not, rarely ..."

Stories in puppetry that are absolutely or directly related to trade and economic economics are very rare. These things are only told as a form of symbolization. For example, prosperity can be achieved through a job, and in a society, in a country, the people have various kinds of supporting livelihoods. With a prosperous society, the country is also prosperous, a manifestation of a welfare concept.

A role model always accompanies the things conveyed in the puppet related to peroconian. One example of exemplary value exemplified in the teachings of materialism and metaphysics. Materialism is a system of thought that believes in the matter as the only absolute existence and rejects the existence of anything other than matter (Lavine 2002). Meanwhile, metaphysics is the root of the tree of knowledge; the tree is physics, while the branches are other branches of science (Kennick 1966).

"Materialism is a teaching that emphasizes the superiority of material factors over the spiritual. Materialism is concerned with worldliness. Whereas all things like that will disappear, with the wind alone it will disappear, run out ".

"The issue of the quality of reality is one of the oldest problems in metaphysics. Spiritualism is the starting point at the core of most stories from this ancient ancestor.'

The two things above are narrated in puppetry as role models or educational media or preaching media that contain noble values; this is the same as what Mulyono (1983) argues. Thus, by conveying these two values, there is a qualitative reflection of accounting in the puppet, even though it is not absolute, but only as a symbol.

Some of the characteristics of an accountant needed include having good morals and ethics to work on correct, efficient, and optimal financial reports. The relationship between these characteristics in puppetry can be correlated with moral and ethical learning that are often conveyed in puppet shows. Several matters concerning morals and ethics described in the puppet by Reki as a resource can be seen in the following quote.

"The learning of morals and ethics in puppetry is generally related to defamation, morals, courtesy, maintaining dignity, self-respect, and so on."

An explanation of the relationship between Wayang and ethics can be found in various works of literature; however, in this case, the study will invite the reader to dive into the writings of Benedict ROG, Anderson and France Marknice and Suseno because these two figures, according to the author can discuss the problems of Wayang in the frame or scientific, ethical point of view (Rusdy 2015:126).

One example of a play or character used as a role model or learning includes Semar, Rama, and Arjuna. Semar is described as virtuous, honest, knightly, daring to face reality, and full of responsibility. It is taught that every human being who is towed or followed by Semar must be virtuous, be more dominant in giving in to win, do more work than talk a lot. Another play is Rama, an Ayodya King, and is depicted as full of compassion for others, not only with 
humans but also with the smallest flying animals he loves. Then Arjuna is a figure who is described as a human being, an ordinary human, and a knight who does not want to give up on the truth.

These figures' values need to be used as role models that should be emulated by all people, not just accountants. Characters such as honesty, virtuousness, the courage to face reality, and full of responsibility and never giving up are ideal character examples for an accountant because an accountant has to report an institution's financial condition to interested parties. This is one part that is quite risky if an irresponsible accountant does it because it can trigger indications of corruption, such as the Seruni play, which then causes huge losses to a country.

\section{CONCLUSION}

Accounting is a social science that is closely related to human behavior in interaction with the surrounding environment. Although positivists say, accounting is a scientific science that requires linear logic, cause and effect, which is analogous to science, in practice, accounting in an institution or setting will "adjust" to the report maker's behavior and social interactions in that setting. Accounting and Wayang are breakthroughs in revealing the relationship between accounting science applied to Javanese society in the past. Historical analysis can be used as a guide in revealing local facts, and we can understand the social characteristics of Javanese society and the interpretation of Javanese culture in its symbolic manifestations in Wayang. This paper attempts to reveal such characteristics that reflect traditional and localized accounting behavior within society. The story of Mahabharata depicts a market as a medium of power and Tondo as an economic actor who pays taxes to the state. The ethics and economic morals taught are honesty, Seruni as the corruptor, and Turo as the honest play. Hence, the qualitative characteristics of accounting in Wayang stories are not shown explicitly, but in symbolization and characterized puppets.

As this study is a preliminary approach to observe local content in accounting study, we recommend conducting further studies on other cultures in Indonesia to obtain in-depth information about Indonesian behavior's fundamental characteristics. So far, we have always obtained accounting knowledge and information, both at university and in real practice, oriented towards western culture. This can result in a distortion of understanding in dissecting trading, financial, and buying and selling activities carried out by a local culture for years. This kind of research will add insight into the interpretation and awareness of the importance of seeing two different perspectives in qualitative accounting.

\section{REFERENCES}

[1] Anderson BROG. 2008. Mitologi dan Toleransi Orang Jawa. Terj. Revianto B.

[2] Bastomi S. 1995. Gemar Wayang. Semarang (ID): Dahara Prize.

[3] Bowen GA. 2009. Document Analysis as a Qualitative Research. Qualitative Research Journal. 9(2):27-40.

[4] Kartikahadi H, Sinaga RU, Syamsul M, Siregar SV. 2016. Akuntansi Keuangan Berdasarkan SAK Berbasis

[5] IFRS. Jakarta (ID): Salemba Empat.

[6] Hermawan S M dan Loo K M. 2019. The Construction of Kekeluargaan as an Indonesia's Organizational Culture. Jurnal Humaniora. 31(1):1-13.

[7] Kennick. 1966. Metaphysics. New Jersey (US): Prentice-Hall. Inc. 
Reflection of Qualitative Characteristics of Accounting in Culture; A Case Study on Wayang in Yogyakarta

[8] Kieso DE, Weygant JJ, Warfield TD. 2016. Intermediate Accounting (IFRS Edition). New Jersey (US): WILEY.

[9] Kusdewanti AI, Setiawan AR, Kamayanti A, Mulawarman AD. 2014. Akuntansi Bantengan: Perlawanan

[10] Akuntansi Indonesia Melalui Metafora Bantengan dan Topeng Malang. Malang (ID): Universitas Brawijaya.

[11] Manan A. 2014. Akuntansi Dalam Perspektif Budaya Jawa: Sebuah Study Etnografi Pada Pedagang

[12] Keliling di Kota Semarang. Jurnal Ilmu Manajemen dan Akuntansi Terapan. 5(1):1-20.

[13] Mulyono S. 1983. Simbolisme dan Mistikisme dalam Wayang. Jakarta (ID): CV Haji Masagung.

[14] Rusdy ST. 2015. Semiotika \& Filsafat Wayang Analisis Kritis Pegelaran Wayang. Jakarta (ID): Yayasan Kertagama.

[15] Sugiyono. 2014. Metode Penelitian Pendidikan. Bandung (ID): Alfabeta.

[16] Sukmadinata NS. 2013. Metode Penelitian Pendidikan. Bandung (ID): PT Remaja Rosdakarya.

[17] Sukoharsono EG. 2009. Spiritual Intelligence Definitions: Availability for Accounting Knowledge. Unpublished Working Paper. Malang (ID): University of Brawijaya.

[18] Sutrisno M dan Putranto H . 2005. Teori - Teori Kebudayaan. Yogyakarta: Kanisius.

[19] Sylvia. 2014. Membawakan Cinta Untuk Akuntansi. Jurnal Akuntansi Multiparadigma. 5(1):139-148.

[20] Tricker RI. 1978. Research in Accounting. Scotland (UK): University of Glasgow Press.

[21] Triyuwono I. 2009. Perspektif, Metodologi dan Teori Akuntansi Syariah. Jakarta (ID): Raja Grafindo Persada.

[22] Lavine TZ. 2002. Pertualangan Filsafat dari Socrates ke Sartre. Yogyakarta (ID): Penerbit Jendela.

[23] Warto, Supariadi, Margana. 2011. Revitalisasi Wayang Beber untuk Memperkokoh Identitas Budaya Bangsa dan Untuk Mendukung Pengembangan Pariwisata Daerah di Kabupaten Pacitan. Surakarta (ID): LPPM UNS (Laporan Penelitian Hibah Bersaing).

[24] Widhianningrum P dan Amah N. 2014. Akuntansi Ketoprak: Sebuah Pendekatan Etnografi Masyarakat Seni Ketoprak di Pati. Jurnal Akuntansi dan Pendidikan. 3(1):75-103.

[25] Zulfikar, Triyuwono I, Ludigdo U, Riduwan A. 2017. The Social Interpretation of Accounting Entity In The perspective of The Semar's Philosophy. International Journal of Business, Economics, and Law. 12(1):34-43. 